\title{
Water Resource Sustainable Utilization Evaluation Index System in Jiangsu Coast Reclamation Region
}

\begin{abstract}
As a comprehensive system, there are many subsystems such as water resource subsystem, social subsystem, economic subsystem and ecological subsystem in water resource sustainable utilization system. In this paper, an evaluation system including three levels is set up according to the metric demands of sustainable water resource utilization in Jiangsu coast reclamation region, namely the target level, the rule level, and the index level. Considering the large number of the indexes, the analytic hierarchy process is used to determine the weights of all these subsystems in the total goal of water sustainable utilization. By analyzing these weights, the attributes of water resource itself is found to be the most important aspect for the evaluation of sustainable utilization in Jiangsu coast reclamation region, and the second important aspect is the situation of the eco-environment.
\end{abstract}

Keywords: water resource, sustainable utilization, index system, index weight, Jiangsu coast reclamation region, analytic hierarchy process.

\section{Introduction}

Sustainable development is the overall strategy of social economic development in all countries and regions around the world, in which sustainable utilization of water resource is a new mode of water resource utilization. With the features of complexity, universality, dynamics, and regionalism, it is the most appropriate utilization of water resource integration of exploitation and utilization, protection and management [1]. An important basis of water resource sustainable management is the scientific evaluation of the environment and economic results of water resource exploitation and utilization, which can be used to find out the existing problems [2,3]. To evaluate water resource exploitation and utilization effectively, the first problem that needs to be solved is the establishment and construction of an evaluation index system. This paper researches and sets up an comprehensive evaluation index system to reflect and measure the water resource sustainable utilization in Jiangsu coast reclamation

\footnotetext{
*Corresponding author: Li Ren, State Key Laboratory of Hydrology-Water Resources and Hydraulic Engineering, Hohai University, Naijing, 210098, China, E-mail: renli@hhu.edu.cn

Xinyi Xiang, School of geographical sciences, Southwest University, Chongqing, 400715, China, ruoqing@swu.edu.cn

Weilin Liu, Jiangxi Provincial Key Laboratory of Hydrology-Water Resources and Water Environment, Nanchang Institute of Technology, Nanchang, Jiangxi, 330099, China, weilin_liu@nit.edu.cn
} 
region, and decides the weight based on the contents of water resource and its exploitation and utilization by analyzing the relationship between water resource and ecological environment, economy, as well as the society. It provides a scientific basis for water resource sustainable exploitation and utilization in Jiangsu coast reclamation region so that it guarantees the sustainable development of the economic society in Jiangsu coast reclamation region.

\section{Concepts of Water Resource Sustainable Utilization}

Water resource sustainable utilization refers to the whole process to support the harmonious development of population, resource, environment and economy, and to satisfy the water demands of generational and intergenerational population, maintaining the sustainability of water and integrity of the ecological system [4]. Therefore, water resource sustainable utilization approach is different from the traditional water resource exploitation and utilization in nature. It considers ecological environment values and social values more than only focusing on basic economic values. It's conducted according to the strategy of harmonious development of population, resource, environment and economy. With a clearly defined objective, it embodies the equity principle for human kind to share the environment, resource and economy, and social benefits. We should follow the idea of "unity, harmony, optimization and cycle", use the systematic method as well as high and new technology in implementation to realize equitable and efficient development [5].

\section{Evaluation Index System of Water Resource Sustainable Utilization in Jiangsu Coast Reclamation Region}

\subsection{The Principles to Set up Evaluation Index System}

The above theory has clearly stated that the evaluation index system of water resource sustainable utilization should display not only the water resource features, its exploitation, utilization and management, which constitute the water resource system development level, but also the harmonious development level of water resource system with social system, economic system, and ecological environment system [6]. Thus we have to follow the subsequent principles when we select indexes to set up the index system [7]:

1. The index should have objective scientificity: The index should objectively reflect the internal relationship of water resource system; provide clear definition, standard measuring methods, and normative calculating methods; and fully reflect the major features and development of water resource exploitation \& utilization in the water basin. 
2. The index should have generality: We should try to select the representative comprehensive index from those that fully reflect the sustainable utilization features of the water resource.

3. The index should have systematic hierarchy: It's requested to set up a systematic and well-organized index system with clear hierarchy to express the complicated problem in a compact, clear and hierarchical index system.

4. The index should have operability: The index should be simple, clear, and easy to be obtained and operated, with high comparability.

\subsection{Hierarchy Structure of the Index System}

The evaluation index system of water resource sustainable utilization can be divided into three levels of target, rule and index based on the measuring demands of water resource sustainable utilization and the construction principles of the evaluation index, referring to the construction methods of sustainable development index system, cyclic economy development index system and other systems, according to the practical situation of Jiangsu coast reclamation region. Reflected by the rule level, the target level has a single target. Composed of three subsystems, the rule level is reflected by the index level, which comprises several quantified indexes to completely show the major factors that influence the water resource sustainable utilization in Jiangsu coast reclamation region. See Table 1 for the composition.

Table 1: Evaluation indexes for water resources sustainable utilization in Jiangsu coast reclamation region

\begin{tabular}{|c|c|c|c|}
\hline Rule level B & Index level C & Unit & Calculation formula \\
\hline \multirow{4}{*}{$\begin{array}{l}\text { Social } \\
\text { subsystem } B_{1}\end{array}$} & Population density $\left(C_{1}+\right)$ & Person $/ \mathrm{km}^{2}$ & Total population/region area \\
\hline & Cultivated land per capita $\left(C_{2}\right)$ & $\mathrm{Ha} /$ person & $\begin{array}{l}\text { Cultivated land area/total } \\
\text { population }\end{array}$ \\
\hline & Urbanization ratio $\left(\mathrm{C}_{3}\right)$ & $\%$ & $\begin{array}{l}\text { Urban population/total } \\
\text { population }\end{array}$ \\
\hline & Fiscal revenue $\left(\mathrm{C}_{4}\right)$ & $\begin{array}{l}\text { Per ten } \\
\text { thousand Yuan }\end{array}$ & See the statistics yearbook \\
\hline \multirow[t]{4}{*}{$\begin{array}{l}\text { Economic } \\
\text { subsystem } B_{2}\end{array}$} & GDP per capita $\left(C_{5}\right)$ & $\begin{array}{l}\text { Per ten } \\
\text { thousand Yuan }\end{array}$ & GDP/total population \\
\hline & GDP per unit water $\left(C_{6}\right)$ & Yuan $/ \mathrm{m}^{3}$ & $\begin{array}{l}\text { GDP/total water resource } \\
\text { amount }\end{array}$ \\
\hline & $\begin{array}{l}\text { Water consumption per unit of GDP } \\
\left(\mathrm{C}_{7}\right)\end{array}$ & $\begin{array}{l}\mathrm{m}^{3} / \text { ten } \\
\text { thousand Yuan }\end{array}$ & Water consumption/GDP \\
\hline & $\begin{array}{l}\text { Water consumption per ten } \\
\text { thousand Yuan GDP }\left(C_{8}\right)\end{array}$ & $M^{3}$ & $\begin{array}{l}\text { Production water } \\
\text { consumption/GDP }\end{array}$ \\
\hline
\end{tabular}


Table 1:

\begin{tabular}{|c|c|c|c|}
\hline Rule level B & Index level C & Unit & Calculation formula \\
\hline \multirow[t]{2}{*}{$\begin{array}{l}\text { Economic } \\
\text { subsystem } B_{2}\end{array}$} & $\begin{array}{l}\text { Irrigation water comprehensive } \\
\text { utilization coefficient }\left(C_{q}\right)\end{array}$ & $\%$ & $\begin{array}{l}\text { Field water consumption/ } \\
\text { water withdrawal at water } \\
\text { intake }\end{array}$ \\
\hline & $\begin{array}{l}\text { Water consumption per ten } \\
\text { thousand value-added of industry } \\
\left(C_{10}\right)\end{array}$ & $\begin{array}{l}\mathrm{m}^{3} / \text { ten } \\
\text { thousand Yuan }\end{array}$ & $\begin{array}{l}\text { Industrial water consumption/ } \\
\text { value-added of industry }\end{array}$ \\
\hline \multirow{8}{*}{$\begin{array}{l}\text { Water } \\
\text { resource } \\
\text { subsystem } B_{3}\end{array}$} & Water resource per capita $\left(C_{11}\right)$ & $\mathrm{m}^{3} /$ person & $\begin{array}{l}\text { Local water resource amount/ } \\
\text { total population }\end{array}$ \\
\hline & Water production modulus $\left(\mathrm{C}_{12}\right)$ & $\begin{array}{l}\text { Per ten } \\
\text { thousand } \mathrm{m}^{3} / \\
\mathrm{km}^{2}\end{array}$ & $\begin{array}{l}\text { Regional water resource } \\
\text { amount/land area }\end{array}$ \\
\hline & $\begin{array}{l}\text { Surface water exploitation and } \\
\text { utilization ratio }\left(C_{13}\right)\end{array}$ & $\%$ & $\begin{array}{l}\text { Annual surface water supply } \\
\text { amount } \times 100 \% / \text { local surface } \\
\text { water resource amount }\end{array}$ \\
\hline & $\begin{array}{l}\text { Ground water exploitation and } \\
\text { utilization ratio }\left(\mathrm{C}_{14}\right)\end{array}$ & $\%$ & $\begin{array}{l}\text { Annual ground water } \\
\text { exploitation amount } \times 100 \% / \\
\text { allowable ground water } \\
\text { exploitation amount }\end{array}$ \\
\hline & Water supply per capita $\left(C_{15}\right)$ & $\mathrm{m}^{3} /$ person & $\begin{array}{l}\text { The ratio between water } \\
\text { supply and total population }\end{array}$ \\
\hline & $\begin{array}{l}\text { Ground water supply percentage } \\
\left(\mathrm{C}_{16}\right)\end{array}$ & $\%$ & $\begin{array}{l}\text { Ground water supply amount/ } \\
\text { available water supply }\end{array}$ \\
\hline & Water supply modulus $\left(\mathrm{C}_{17}\right)$ & $\begin{array}{l}\text { Ten thousand } \\
\mathrm{m}^{3} / \mathrm{km}^{2}\end{array}$ & $\begin{array}{l}\text { Water supply amount/water } \\
\text { supply area }\end{array}$ \\
\hline & $\begin{array}{l}\text { Water resource exploitation rate } \\
\left(C_{18}\right)\end{array}$ & $\%$ & $\begin{array}{l}\text { Exploitation amount/total } \\
\text { water resource amount }\end{array}$ \\
\hline \multirow[t]{3}{*}{$\begin{array}{l}\text { Ecological } \\
\text { subsystem } B_{4}\end{array}$} & Dilution ratio $\left(\mathrm{C}_{19}\right)$ & $\%$ & $\begin{array}{l}\text { Sewage discharge amount/ } \\
\text { surface runoff }\end{array}$ \\
\hline & Sewage treatment ratio $\left(C_{20}\right)$ & $\%$ & $\begin{array}{l}\text { Sewage polluting input/total } \\
\text { sewage discharge amount }\end{array}$ \\
\hline & $\begin{array}{l}\text { Ecological environment water } \\
\text { consumption ratio }\left(C_{21}\right)\end{array}$ & $\%$ & $\begin{array}{l}\text { Ecological environment water } \\
\text { consumption amount/total } \\
\text { water consumption amount }\end{array}$ \\
\hline
\end{tabular}

1. Target level A: The target of water resource sustainable utilization evaluation in Jiangsu coast reclamation region is to give a comprehensive evaluation of the comprehensive water resource utilization level in coast reclamation region and to provide decision basis for the sustainable development in the region. 
2. Rule level B: Rule level is composed of four subsystems: social subsystem, economic subsystem, water resource subsystem, and ecological subsystem. It shows the influence of each subsystem in the index system on the sustainable utilization comprehensive index. This is the core subsystem and main body. The social and economic subsystems refer to the human kind and the surroundings, as well as the industry structure and economic benefits.

3. Index level $C$ : It's a group of basic indexes that describe the status of sustainable development. The indexes which are frequently used in comprehensive evaluation research of the current water resource sustainable utilization are selected to show the universality of the index system. In addition, we also pay attention to the feasibility and comparability of the indexes, trying the best to use the existing statistics data.

\section{Determine the Evaluation Index Weight}

\subsection{Analytical Method}

Analytic Hierarchy Process (AHP) is a flexible and simple multi-criteria decision making method proposed by an American scholar, Professor T. L. Saaty. At first, to decompose a complicated system into several levels. The specialists evaluate the importance of the indexes in each level and then determine the weight coefficient of each subsystem in the total goal by calculating the contribution degree (weight) of the lower layer indexes to the upper layer indexes. This paper uses AHP to determine the weight coefficient of social, economic, water resource and ecological subsystems in water resource sustainable utilization comprehensive evaluation.

\subsection{Figure Captions}

1. Establish the Judgment Matrix: Decide the relative importance between every two elements in the lower layer according to a certain element in the upper layer, quantize them, and constitute a matrix form, which is a judgment matrix.

$$
A=\left[\begin{array}{cccc}
a_{11} & a_{12} & \cdots & a_{1 n} \\
a_{12} & a_{22} & \cdots & a_{2 n} \\
\vdots & \vdots & \vdots & \vdots \\
a_{n 1} & a_{n 2} & \cdots & a_{n n}
\end{array}\right]
$$

2. Evaluate the Geometric Mean of Elements of Each Row:

$$
b_{i}=\left(\prod_{a_{i j}}^{m} a_{i j}\right)^{1 / m}, \quad i=1,2, \cdots, m
$$

3. Calculate the Weight Coefficient:

$$
\omega_{j}=b_{j} / \sum_{R=1}^{m} b_{R}, \quad j=1,2, \cdots, m
$$


4. Evaluate the Maximum Feature Root of Judgment Matrix:

$$
\lambda_{\max }=\frac{1}{m} \sum_{i=1}^{m}\left(\sum_{j=1}^{m} a_{i j} \omega_{j} / \omega_{j}\right)
$$

5. Consistency Check:

$$
\begin{aligned}
& C R=C I / R I \\
& C I=1 / m-1 \times\left(\lambda_{\max }-m\right)
\end{aligned}
$$

In the above formula, CR is the random consistency ratio of the judgment matrix; CI is the general consistency index of the judgment matrix; RI is the average random consistency index (referring to the table) of the judgment matrix; $m_{\text {is }}$ the order of the judgment matrix. $C R<0.1$ indicates that the constituted judgment matrix meets the requirements well.

Table 2: The weights of evaluation indexes for water resources sustainable utilization in Jiangsu coast reclamation region

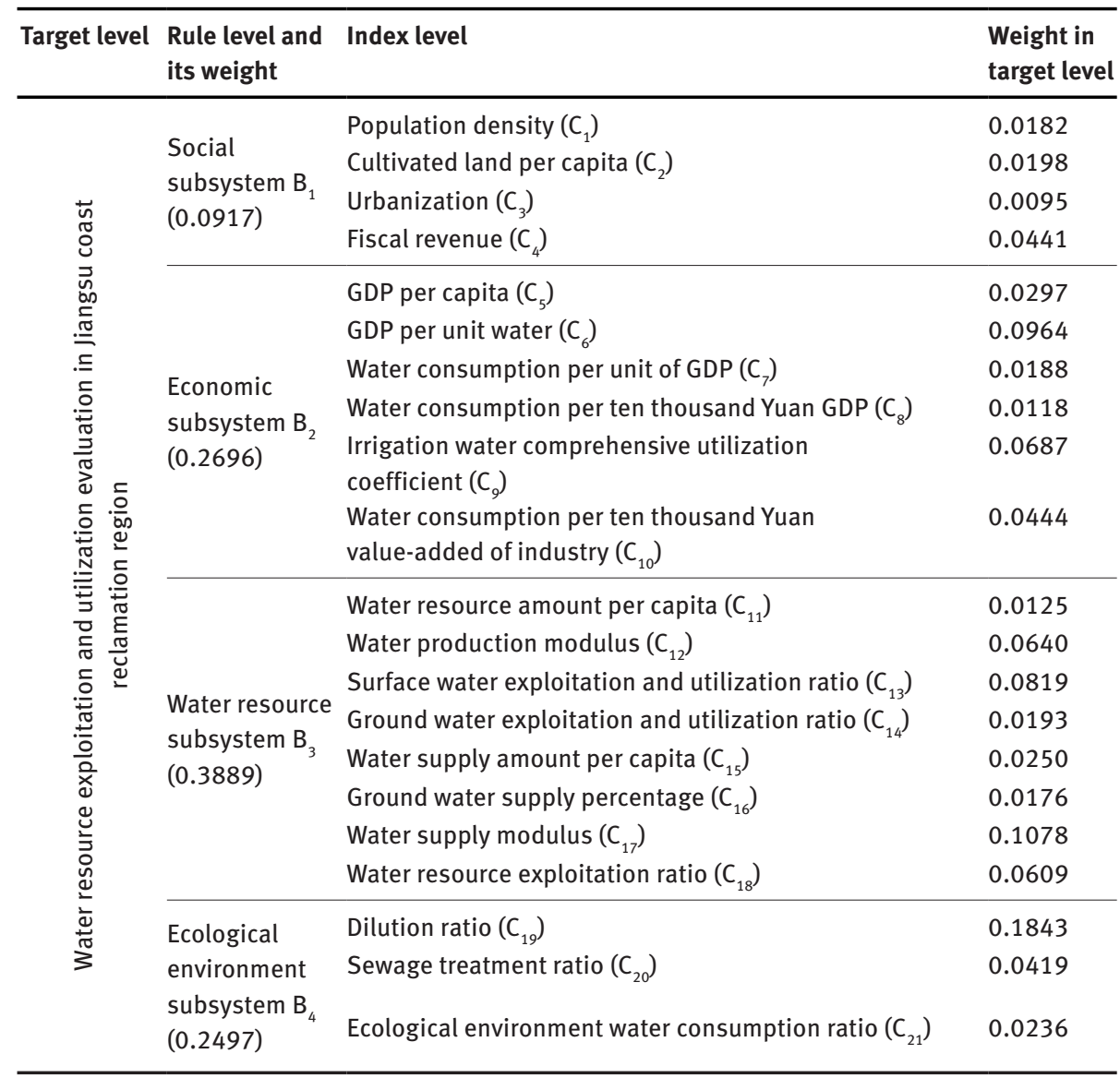


As shown in Table 2, the weight of 4 indexes in rule level and 21 indexes in index level can be calculated based on the above formula. The consistency check should be implemented as required to eliminate the error caused by subjective judgment. The results of weight consistency check are: $0.0820,0.0047,0.0228,0.0734,0.0123$, which are all less than 0.1. It shows that the weight calculation results meet the consistency and the judgment matrix works successfully.

\section{Determine the Evaluation Index Weight}

To evaluate water resource sustainable utilization, we need to conduct a comprehensive research by combining social economic development and ecological environment protection with water resource status. Therefore the paper sets up a hierarchical evaluation index system that reflects the relationship between water resource, society, economy, and ecological system in Jiangsu coast reclamation region. The proposed index system is a 3-level hierarchical structure composed of target level, rule level, and index level. The specific 21 indexes in it can provide a complete map of the harmonious relationship between water resource and local natural status as well as human activities. Deciding the index weights based on AHP greatly reduces the subjective biases and makes the index configuration more appropriate. It can be found out according to the analysis on index weight value that the nature of the water itself is the most important aspect to measure water resource sustainable utilization in Jiangsu coast reclamation region. And the influence of the ecological environment on water resource sustainable utilization comes next.

All in all, we select proper index evaluation method to make the evaluation based on the determination of indexes and their weights. We discover problems and make proposals to solve the problems; so that we can guide the practice of water resource exploitation and utilization to improve the sustainable development of the ecological environment and social economy.

Acknowledgement: This research was supported by the Jiangsu Province Natural Science Foundation (BK20130842), the Project supported by the National Natural Science Foundation of China (51409091, 51309130) and the Fundamental Research Funds for the Central Universities (2015B14614).

\section{References}

[1] Tang L., Zhang W.B., Research on assessment index system for sustainable utilization of urban water resources[J], J.amam, 2012, 212-213, 569-573.

[2] Gai W.Q., Innovation networks-regional economic development[M]. Beijing: Peking University Press, 2002: 16-30. 
[3] Hakansson H. Corporate Technological Development: Cooperation and Networks[M]. London: Routledge, 1987: 120-123.

[4] Feng S.Y., An introduction to the sustainable utilization of water resources and the management[M].Beijing: Science press, 2000: 62-214.

[5] Yang J.J., Zhou J., An integrated model for simulating and evaluating water resources sustainability at laoshan region[J]. J.amam, 2014, 675-677, 880-885.

[6] Feng L.H., Zhang X.C., Luo G.Y., Application of system dynamics in analyzing the carrying capacity of water resources in Yiwu City, China[J]. J.macis, 2008, 79(3), 269-278.

[7] Lou Y.H., Kang S.Z., Cui N.B., Yang H.X., Establishment and application of comprehensive evaluation model for water-saving development level of irrigation management in Sichuan province[J]. J.totcsoae, 2014, 30(4), 79-89. 